\title{
A Study on the Impact of Information Technology (IT) on the Performance of Commercial Banks in Oman
}

\author{
Maryam Humaid Alwashahi \\ Sohar University
}

\begin{abstract}
The economic development of any country depends on the growth and development of the banking sector. The Banking sector is considered to be an effective instrument for accelerating the pace of economic growth. The economic status of Sultanate of Oman has reached the present position due to the continuous efforts by the government for enhancing the quality and productivity of banking operation. This paper has carried out an extensive investigation into the impact of the information technology (IT) on the performance of commercial banks in Oman. The investigation has been done on eight important commercial banks. The work has unearthed that, the nowadays the growth of IT field has penetrated the banking sector in Oman, which in turn, has accelerated the performance of commercial banks on one hand and the customer satisfaction on the other. At the end, there are some recommendations for further improvement of IT system in banking sector in Oman.
\end{abstract}

\section{Keywords}

Banking sector, Information technology (IT) , performance evaluation.

\section{INTRODUCTION}

The role of commercial banks in the economic development of a country is inevitable for the reason, that the banking sector stands to be an effective tool for transferring the individual savings in the capital formation of a country (Brooking, 2001). The success or failure of any economic system is based on the functioning of commercial banks in a country. Therefore, important for a nation to look into the planning and implementation of a good banking system so that the pace of economic growth is accelerated to achieve the goals set forth by a government (Lamb, 2003). Oman is considered to be one the countries in the GCC which has witnessed remarkable growth in the banking sector by encouraging the infrastructural changing both in the operation of the banks and in the delivery of banking services to the customers. The growth and development, IT system have dominated all fields of economic activities in the country. The Banking sector is one the most influenced sectors by the invent of IT system. Therefore, has developed an interest in undertaking a study on the impact of IT system on the performance of the commercial banks in Oman

\section{LITERATURE REVIEW}

Commercial bank is the term used for a normal bank to distinguish it from an investment bank. This is what people normally call a "bank". The term "commercial" was used to distinguish it from an investment bank. Since the two types of banks no longer have to be separate companies, some have used the term "commercial bank" to refer to banks which focus mainly on companies. In some English-speaking countries outside North America, the term "trading bank" was and is used to denote a commercial bank[16].

In modern banking system, commercial banks have made to see the change in the functioning of commercial transactions. The functions of a commercial bank can be three folded:

- $\quad$ Accepting deposits

- Lending Loans

- Ancillary functions

A commercial bank lends different types of loans which can be categorized as cash, credit, overdraft and term loans. Loans can also be classified into short-term, medium term and long term on the basis of the period of the loan. Loans are granted by commercial banks for different purposes, for both for business and non-business customers. Personal loans are offered to non-business customers for different purposes at a reasonable rate of interest with easy instalments. Loans are also offered to business people for different business purposes [12].

In modern banking system, a commercial bank undertakes a lot of ancillary functions for the customers. These are known as a service function. The role of commercial banks in service functions has increased to a great extent that a bank is doing agency function in everything for their customers [7].

\section{AN OVERVIEW OF BANKING SECTOR IN OMAN}

Banking sector plays a vital role in achieving financial equilibrium and economic stability in any country. Banking sector in Oman is viewed as a most stable and fast growing sectors in the GCC region, operating in such a way as to respond to the regional and global developments and requirements and the need for changes towards the Globalization. In Oman, the central bank of Oman is responsible for maintaining the stability of national currency the Omani Rial (OR) and ensuring monetary , financial stability in a deregulated and open financial system. The Omani banking system has experienced several mergers and many specialized banks have been incorporated during the past five years, namely, Oman Housing Bank,

\section{INFORMATION TECHNOLOGY AND BANKING SECTOR}

The influence of information technology has become inevitable in each and every aspect of the life. E-commerce 
has opened up a revolutionary change in the operation of business enterprises, whether it is manufacturing organization or a service organization. The impact of information technology is very high in the service sector in general and in the banking sector in particular. The use of information technology has led to a sea change in the functioning of the banking sector over the world. The IT strategies have opened up new markets, new products, new services and excellent delivery of banking services. Gone are the days where the customers of commercial bank stood in a queue in front of the banks' counter during the specified office hours for transacting any banking operations. But there is a different scenario in the present day IT era, where the customers visit the bank on the day of opening the account and are able to carry out all the banking operations in absentia through the use of IT based banking services such as Online electronic banking, mobile banking and internet banking .

\section{PROBLEM STATEMENT}

Under a competitive environment, banking organizations are striving to provide the finest services to their customers to retain a position in the competitive market. The efforts are being directed to achieve a high level of customer satisfaction. An organization cannot exist without the attaining customer satisfaction. The banking sector has made a remarkable growth in Sultanate of Oman under the captainship of the Central Bank of Oman. Being the Apex Bank, the Central Bank of Oman plays a major role in the creation and maintenance of a well-organized banking system in the country. It is a well-known fact among the economists that a well-organized banking system is a prerequisite for the economic growth of a country. Banks act as instruments for capital formation which is the basis for the growth of the economy in the country.

In Oman three types of banks are functioning which are:

\section{Government Banks \\ 2. Private Sector Banks \\ 3. Multinational Banks}

All these three types of banks participate in commercial banking activities. There exists a stiff competition among the commercial banks to gain the market share and achieve higher customer satisfaction. In this context, the researcher has developed an interest to study about the impact of information technology on the performance commercial banks in the Sultanate of Oman.

\section{OBJECTIVES OF THE STUDY}

The overall aim of the study is to evaluate the impact of information technology on the performance of the commercial banks in the Oman banking sector. Keeping the broad aim in mind the following specific objectives are framed:

1. To assess the IT strategies followed by commercial banks in Oman;

2. To assess the utility of IT facilities by the customers;

3. To evaluate the impact of IT strategies on the performance of the banks;

4. To identify the problems faced by the commercial banks in the implementation of IT strategies;
5. To offer findings, suggestions and conclusions

\section{HYPOTHESIS}

The following hypothesis have been framed :

1. The information technology system introduced in commercial banks has not influenced the performance of banks in Oman.

2. The information technology system in commercial banks has not influenced the level of customer satisfaction.

\section{RESEARCH METHODOLOGY}

The study is an empirical research based on the survey method. Both primary and secondary data will be collected for the purpose of the study. The researcher has proposed to collect primary data both from samples of commercial banks in Oman and their customers through structured questionnaires.

The secondary data regarding the theoretical aspects of IT strategies in the banking sector, will be collected from recognized text books, journals, newspapers, research articles and research works and from relevant websites.

Sampling design:

For the purpose of the study, eight locally incorporated commercial banks in Oman are selected. The sample population for the study includes the following banks:

1. Ahli bank;

2. Bank Muscat

3. Bank Dhofar

4. Oman International Bank, now merged with HSBC

5. Oman Arab Bank;

6. Bank Sohar

7. Bank Nizwa

8. National bank of Oman

The researcher has excluded the foreign banks operating in Oman for the study. For this study , 10 customers has been selected for each banks for this study,so the total around 80 customers in order to collect primary data from the customers. Hence, the primary data would be collected through two different questionnaires, one for the commercial banks and the other for the customers.

\section{ANALYSIS AND INTERPRETATION}

The data collected from the questionnaires have been analysed and the following are the outcomes of the analysis:

The IT system introduced by commercial banks has influenced the performance of the banks in positive way. This is evident from the results of analysis made on the performance records of sample population which shows that majority of the sample population considered for the study has recorded an increase in the volume of banking operation ranging from $35 \%$ to $52 \%$; The IT system introduced by the commercial banks in Oman has influenced the level of customer satisfaction as is evident from the analysis that mojority of the customers expressed their happiness in availing the IT based banking transactions which has reduced 
their efforts to the services.

\section{SOME OF SUGGESTIONS TO BE CONSIDERED IN THE MANAGEMENT OF THE BANK}

Would like to record the following suggestions to be considered by the management of banks in order to enhance the quality of IT system:

1. The web page of banks should be designed to be users friendly as the majority of the customers may not be familiar with the handling of computers professionally;

2. The employees of the banks should be trained to acquire the skills and knowledge in IT system to ensure effective discharge of their services; The banks may conduct annual workshops for the customers to make aware of IT system in the banks

\section{CONCLUSION}

Banks play a pivotal role to acceleration of the pace of the economic activities in a country. The called IT system has dominated all fields of business activities with a higher level of influence in banking sectors. This paper has investigated the role of IT system in enhancing the performance of commercial banks in Oman. The findings of the research work show that IT system has a positive impact on the performance of the commercial banks and the level of customer satisfaction. IT play an important role in the most of economic business in the world.

\section{REFERENCES}

[1] Applehans, Wayne, Globe, Alden and Laugero, (2000), "Information Technology as Business strategy", Boston, MA: Addison-Wesley

[2] Award, E.M., (2000), "Building Expert Systems", Minneapolis, MN: West Publishing Co.

[3] Bell, D. (2000) "The coming of post-industrial society", London: Oxford University Press

[4] Bexar C. (2002), "Information Technology Industry Trend", Knowledge Management Journal, May, PP. 2227
[5] Botkin, J (1999), "Smart Business: How knowledge, communication can revolutionize your company", New York: Free Press

[6] Brooking, A (2001), "Intellectual Capital", London: Thompson Press

[7] Don Wright and Wally Valentine, (1999), "Business of Banking and Financial Services" Third Edition, Northcote Publication.

[8] Edwards, D.L. and Mahling, E.L. (2006), "Towards Knowledge management systems in the legal domain", Journal of Information Technology, PP 75-79

[9] Flash, C. (2001), "IT strategy”, New York: Basic Books

[10] Gummesson, E. (2000), "Qualitative methods in Management Research", 2nd edition, Thousand Oak, CA Sage.

[11] Hansen, Morten, Nohria, Nitin and Tierney, and Thomas (2004), "What is your strategy for competitive strengths?", Harvard Business Review, March- April, 2004, PP 106-109

[12] Horibe, F., (2007), "Managing IT strategy", New York: John Wiley \& Sons, Inc.

[13] Lamb, R. (2003), "Using intranets: preliminary results from a socio-technical field study", in proceedings of Hawaii International Conference on system Sciences, Maui, Hawaii

[14] Saunders et al. (2007), "Research Methods for Business Students", 4th edition, Pearson Education Limited, England

[15] Ward, L. (2006), "Collaborative Knowledge Management Tools: Putting Customer Care Online", Knowledge Management Journal, April, 2006, PP CS1 CS6

[16] Zeithaml, Valarie A, Parasuraman, A and Leonard L, (1990), "Delivery Quality Service", New York, Free Press 